\title{
An optimized animal model for partial and total skin thickness burns studies ${ }^{1}$
}

\author{
Um modelo animal aperfeiçoado para estudo de queimaduras superficiais e profundas da pele
}

\author{
Ana Paula Bomfim Soares CampeloI, Marcio Wilker Soares Campelo" ${ }^{\text {II }}$, Gerly Anne de Castro Britto ${ }^{\mathrm{III}}$, Alejandro Pedro Ayala ${ }^{\mathrm{IV}}$, \\ Sergio Botelho Guimarães ${ }^{\mathrm{v}}$, Paulo Roberto Leitão de Vasconcelos $^{\mathrm{VI}}$ \\ IFellow Master Degree, Department of Surgery, Postgraduate Program, UFC, Fortaleza, Brazil. Technical procedures, acquisition and interpretation \\ of data. The article is part of a Master Degree dissertation. \\ IIFellow PhD Degree, Department of Surgery, Postgraduate Program, UFC, Fortaleza, Brazil. Technical procedures and interpretation of data. \\ IIIPhD, Associate Professor, Department of Morphology, UFC, Fortaleza, Brazil. Technical procedures and interpretation of data. \\ ${ }^{\text {IV }} \mathrm{PhD}$, Associate Professor, Department of Physics, UFC, Ceara, Brazil. Technical procedures and interpretation of data. \\ ${ }^{\vee} \mathrm{PhD}$, Associate Professor, Department of Surgery, Head, LABCEX, UFC, Ceara, Brazil. Manuscript writing, statistical analysis, graphics design. \\ ${ }^{\mathrm{V}} \mathrm{PhD}$, Associate Professor, Coordinator, Postgraduate Program, Department of Surgery, UFC, Ceara, Brazil. Tutor, responsible for conception, \\ design, intellectual and scientific content of the study, critical analysis, final approval of manuscript.
}

\begin{abstract}
PURPOSE: Development of an improved animal model for studying skin burns in rats.

METHODS: Twenty-four male Wistar rats were randomly assigned to four groups (n=6): G1-Control, G2- $\mathrm{T} 100^{\circ} \mathrm{C}, \mathrm{G} 3-\mathrm{T} 150^{\circ} \mathrm{C}$ and G4-T $200^{\circ} \mathrm{C}$. Two $10 \times 10 \mathrm{~mm}$ squares were outlined with a sterile surgical marker on each side and along the vertebral column using a prepared template positioned between the anterior and posterior limbs. G2-G4 rats were subjected to $100^{\circ} \mathrm{C}, 150^{\circ} \mathrm{C}$ and $200^{\circ} \mathrm{C}$ thermal burns, respectively. G1 rats served as controls. Burns were inflicted by applying a copper plate connected to an electronic temperature controlling device to the dorsal skin of anesthetized rats. Four burns were produced on each animal (total area: $4 \mathrm{~cm}^{2} /$ animal) leaving about $1 \mathrm{~cm}$ of undamaged skin between burn areas. Analgesia was administered during $24 \mathrm{~h}$ after burn injury by adding $30 \mathrm{mg}$ codeine phosphate hemihydrate to $500 \mathrm{ml}$ tap water.

RESULTS: The application of $100^{\circ} \mathrm{C}$ and $150^{\circ} \mathrm{C}$ resulted in partial thickness skin burns with central reepithelialization of the burned area only at $100^{\circ} \mathrm{C}$. In G4 group the whole thickness of the skin was injured without central reepithelialization. However, there was marginal reepithelialization in all groups.
\end{abstract}

CONCLUSION: The model studied is inexpensive and easily reproducible, enabling the achievement of controlled burns with partial or total impairment of the skin in experimental animals.

Keywords: Models, Animal. Hot Temperature. Burns. Rats.

\section{RESUMO}

OBJETIVO: Desenvolvimento de um modelo animal aperfeiçoado para estudo de queimaduras cutâneas em ratos.

MÉTODOS: Vinte e quatro ratos Wistar, machos, foram distribuídos aleatoriamente em quatro grupos (n=6): G1-Controle, G2-T100 ${ }^{\circ} \mathrm{C}$, $\mathrm{G} 3-\mathrm{T} 150^{\circ} \mathrm{C}$ e G4-T2 $00^{\circ} \mathrm{C}$. Dois quadrados medindo $10 \times 10 \mathrm{~mm}$ foram delineados com um marcador cirúrgico estéril em cada lado e ao longo da coluna vertebral e posicionados entre os membros anteriores e posteriores, utilizando um molde previamente preparado. Os ratos dos grupos G2-G4 foram submetidos a queimaduras térmicas de $100^{\circ} \mathrm{C}, 150^{\circ} \mathrm{C}$ e $200^{\circ} \mathrm{C}$, respectivamente. $\mathrm{O}$ grupo $\mathrm{G} 1$ foi utilizado como controle. As queimaduras foram infligidas pela aplicação de uma placa de cobre, ligada a um dispositivo de controle eletrônico de temperatura, na pele dorsal de ratos anestesiados. Quatro queimaduras foram produzidas em cada animal (área total: 4 $\mathrm{cm} 2$ /animal), deixando cerca de $1 \mathrm{~cm}$ de pele intacta entre as áreas queimadas. Analgesia foi obtida durante 24 horas após a queimadura por adição de $30 \mathrm{mg}$ de fosfato hemi-hidratado de codeína a $500 \mathrm{ml}$ de água potável.

RESULTADOS: A aplicação $100^{\circ} \mathrm{C}$ e $150^{\circ} \mathrm{C}$ resultou na produção de queimaduras profundas comprometendo parte da espessura da pele, com reepitelização central da área queimada, somente a $100^{\circ} \mathrm{C}$. No grupo $\mathrm{G} 4$ houve lesão de toda a espessura da pele sem reepitelização central. Entretanto, observou-se reepitelização marginal em todos os grupos estudados.

CONCLUSÃO: O modelo estudado é de baixo custo e facilmente reproduzível, propiciando a obtenção controlada de queimaduras com comprometimento parcial ou total da pele, em animais experimentais.

Descritores: Modelos Animais. Temperatura Alta. Queimaduras. Ratos. 


\section{Introduction}

Induction of experimental burns in animal models is an essential tool to understand the pathogenesis of skin damage due to burns in humans and for designing new methods of treatment. Animal models have been used to investigate burn wound pathology, local therapy ${ }^{1}$, the influence of systemic drug application on the burn wound and the effect of burn trauma on the entire organism ${ }^{2}$. Inconsistency and irreproducibility are commonly found in experimental studies. Two factors may be related to the controversial and different findings presented in the available literature: burn models are not identical or different modalities of treatment are used by researchers.

The present study was therefore undertaken to determine the optimal experimental model of burns heat-induced by direct conduction in rats, correlating standardized temperatures and lesion depths (partial or total skin thickness burn).

\section{Methods}

Approval for experimental use of laboratory animals was obtained on September, 2010 (Protocol \#37/10) from the Ethics Committee on Animal Research (CEPA) of the Federal University of Ceara, now Ethics Committee on the Use of Animals (CEUA), in view of the Federal Law No. 11794 of October 8, 2008, http:// www.planalto.gov.br/ccivil_03/_Ato2007-2010/2008/Lei/ L11794.htm and Decree No. 6689 of July 15, 2009 that regulated the Law 11794, available at: http://www.planalto.gov.br/ccivil_03/ _Ato2007-2010/2009/Decreto/D6899.htm.

The study was designed to minimize the number of animals required for the experiments. The animals were housed in polypropylene cages at ambient temperature of $24^{\circ} \mathrm{C}$ on a $12 \mathrm{~h}$ light-dark cycle.

\section{Study design}

Twenty-four male Wistar rats were randomly assigned to four groups ( $\mathrm{n}=6$ ): G1-Control, G2-T $100^{\circ} \mathrm{C}, \mathrm{G} 3-\mathrm{T} 150^{\circ} \mathrm{C}$ and $\mathrm{G} 4-$ $\mathrm{T} 200^{\circ} \mathrm{C}$. Two $10 \mathrm{x} 10 \mathrm{~mm}$ squares were outlined with a sterile surgical marker on each side and along the vertebral column using a prepared template (an X-ray film with a $10 \times 10 \mathrm{~mm}$ grid) positioned between the anterior and posterior limbs. G2-G4 rats were subjected to $100^{\circ} \mathrm{C}, 150^{\circ} \mathrm{C}$ and $200^{\circ} \mathrm{C}$ thermal burns, respectively. G1 rats served as controls. Immediately before inflicting the burn, the area was shaved with a standard electric shaving machine to obtain a smooth surface and hairless skin. The dorsal skin was surgically prepared with successive applications of $2 \%$ chlorhexidine scrub. A previously described model ${ }^{3,4}$ was used with some modifications. The original tip of an ordinary $40 \mathrm{~W}$ soldering iron was replaced with tip and square $10 \mathrm{x} 10 \mathrm{~mm}$ copper plate. An electronic temperature controller with a thermocoupletype feedback sensor was connected $2 \mathrm{~mm}$ above the plate tip in order to allow precise optimal temperature monitoring at the tip of the instrument. Additionally, a digital multimeter with a $\mathrm{K}$ type thermocouple was fixed to the copper plate to assure real time optimal control of the temperature applied to the skin (surface counter). The desired stamp temperature $\left(100^{\circ} \mathrm{C}, 150^{\circ} \mathrm{C}\right.$ and $\left.200^{\circ} \mathrm{C}\right)$ was reached $5 \mathrm{~min}$ after switching on the electric current. The device was positioned vertically under its own weight $(85 \mathrm{~g})$ and applied to each skin burn site during 9 seconds to inflict the burns as outlined. Immediately after each burn injury, the respective wound was cooled off during $1 \mathrm{~min}$ with gauze embedded in isotonic saline at $22^{\circ} \mathrm{C}$, as described elsewhere ${ }^{5}$. The plate produced a burn area of approximately $1 \mathrm{~cm}^{2} /$ wound. Four burns were produced on each animal $\left(4 \mathrm{~cm}^{2} /\right.$ animal $)$ leaving approximately $1 \mathrm{~cm}$ intact skin between burn areas. Following conclusion of the procedure, the animals were returned to their individual cages for recovery with free access to rat chow and tap water. Analgesia was administered during $24 \mathrm{~h}$ after burn injury by adding $30 \mathrm{mg}$ codeine phosphate hemihydrate to $500 \mathrm{ml}$ tap water.

\section{Anesthesia}

Anesthesia was induced with an intramuscular injection of ketamine hydrochloride $(90 \mathrm{mg} / \mathrm{kg})$ and xylazine $(10 \mathrm{mg} / \mathrm{kg})$ to all rats.

\section{Macroscopic analysis}

Anesthetized rats were photographed in the seventh day post-burn under anesthesia and standard lighting conditions using a tripod-mounted digital camera (Sony DSC-W35, 7.2 mega pixels) with a constant $1.0 \times$ zoom at $35 \mathrm{~cm}$ distance from the dorsum of the animal. The Images (format TIFF, 512 x 384 pixels) were calibrated and the wound surface area $\left(\mathrm{mm}^{2}\right)$ and perimeter $(\mathrm{mm})$ were calculated by computerized planimetry using the software Image Tool 3.0 (University of Texas Health Center at San Antonio).

\section{Histopathology}

At the end of the experiments all animals were killed by an overdose of anesthetics (Ketamine+xylazine). Tissue samples were collected from the dorsum with a surgical blade, removing skin fragments (20 mm x $5 \mathrm{~mm}$ ), including the central scar, adjacent healthy tissue and underlying panniculus carnosus muscle. Tissue samples were fixed in formalin for 24 hours before being transferred to $70 \%$ ethanol solution. Further processing included paraffin embedding and sectioning, to generate 5 - $\mu$ m-thick tissue coronal sections to be mounted on glass slides. The slides were stained using hematoxylin and eosin. The extent of skin damage was assessed by a blind pathologist using a light microscope (Olympus, X100).

\section{Statistical analysis}

Graphpad Prism 5.0 (GraphPad Software, www.graphpad.com) was used for statistical analysis and graphics design. Data from images (wound surface area and perimeter) were tested for distribution (Kolmorogov-Smirnov test). Results were expressed as mean+SD. Groups were compared at different temperature $\left(100^{\circ} \mathrm{C}, 150{ }^{\circ} \mathrm{C}\right.$ and $\left.200^{\circ} \mathrm{C}\right)$ using Student's $t$ test for unpaired variables. The level of statistical significance was set at $5 \%$. Histopathology findings were tabulated for descriptive analysis. 


\section{Results}

No infection or mortality was observed during the experiments and no systemic complications were clinically detectable.

\section{Macroscopic analysis}

Wound surface area and perimeter (Figures 1 and 2) shown by digital planimetry did not differ significantly when comparing $\mathrm{G} 2\left(\mathrm{~T} 100^{\circ} \mathrm{C}\right)$ and $\mathrm{G} 3\left(\mathrm{~T} 150^{\circ} \mathrm{C}\right)$ groups $(\mathrm{p}>0.05)$. However, wound surface area in $\mathrm{G} 4\left(\mathrm{~T} 200^{\circ} \mathrm{C}\right)$ rats was larger than in G2 group by Student's paired t test $(\mathrm{p}<0.03)$. The same was true for wound perimeter $(\mathrm{p}<0.04)$ (Figure 3$)$.
$100{ }^{\circ} \mathrm{C}$

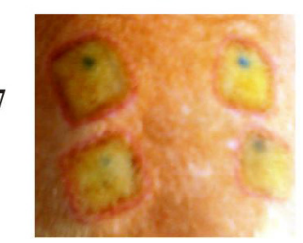

$150{ }^{\circ} \mathrm{C}$

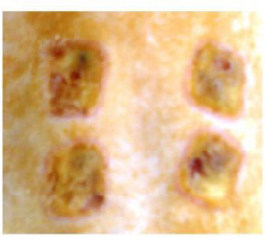

$200{ }^{\circ} \mathrm{C}$

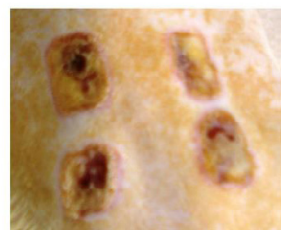

FIGURE 1 - Macroscopic appearance of burns on post-burn day 7.

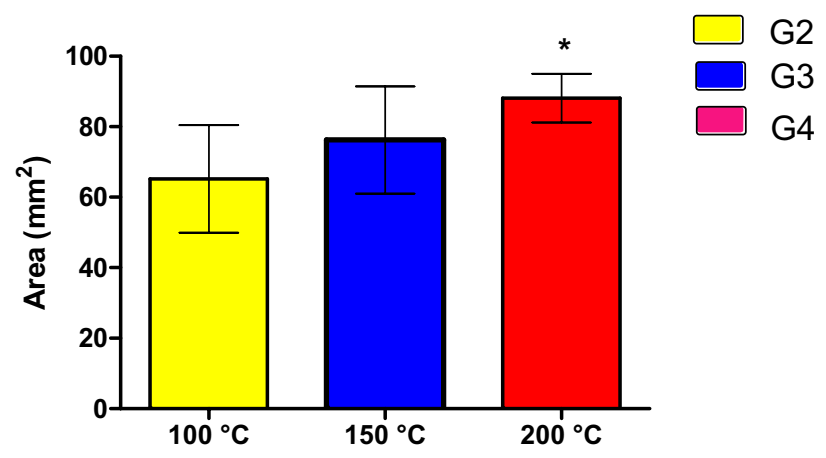

FIGURE 2 - Mean wound surface area injury in rats burned. Bars represent mean $\pm \mathrm{SD}$. ${ }^{*} \mathrm{p}<0.03$.

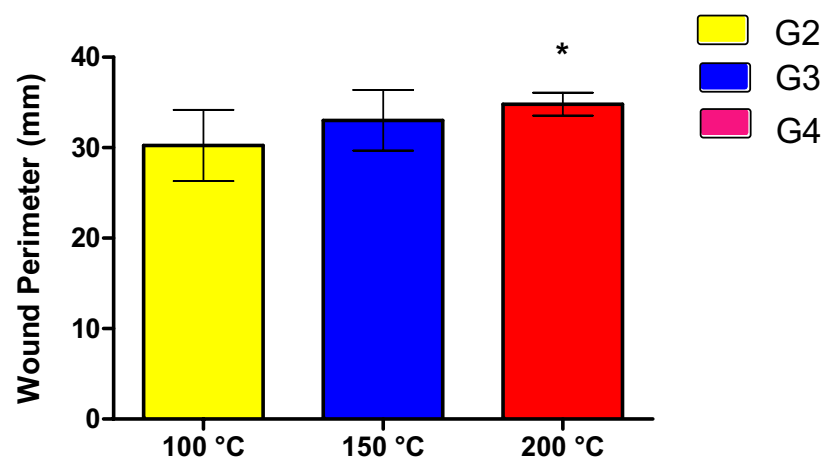

FIGURE 3 - Mean wound perimeter injury in rats burned. Bars represent mean $\pm \mathrm{SD}$. ${ }^{*} \mathrm{p}<0.04$.

\section{Microscopic analysis}

Scars were present in all wounds along incipient marginal reepithelization (Figure 4, images E, G and J). Incipient central reepithelialization was present in G2 only (Figure 4, image F). The dermis presented obliterated vessels and partially damaged pilosebaceous units in groups G2 and G3 (Figure 4, images C, E and $\mathrm{H}$ ). Total dermis and muscle damage were found in $\mathrm{G} 4$ rats (Figure 4, images $\mathrm{J}$ and L). Musculature layers were preserved in $\mathrm{G} 2$ and G3 rats (Figure 4, images D and I, respectively). Table 1 depicts the Presence/absence of skin structures and reepithelialization in $\mathrm{G} 2-\mathrm{G} 4$ rats.
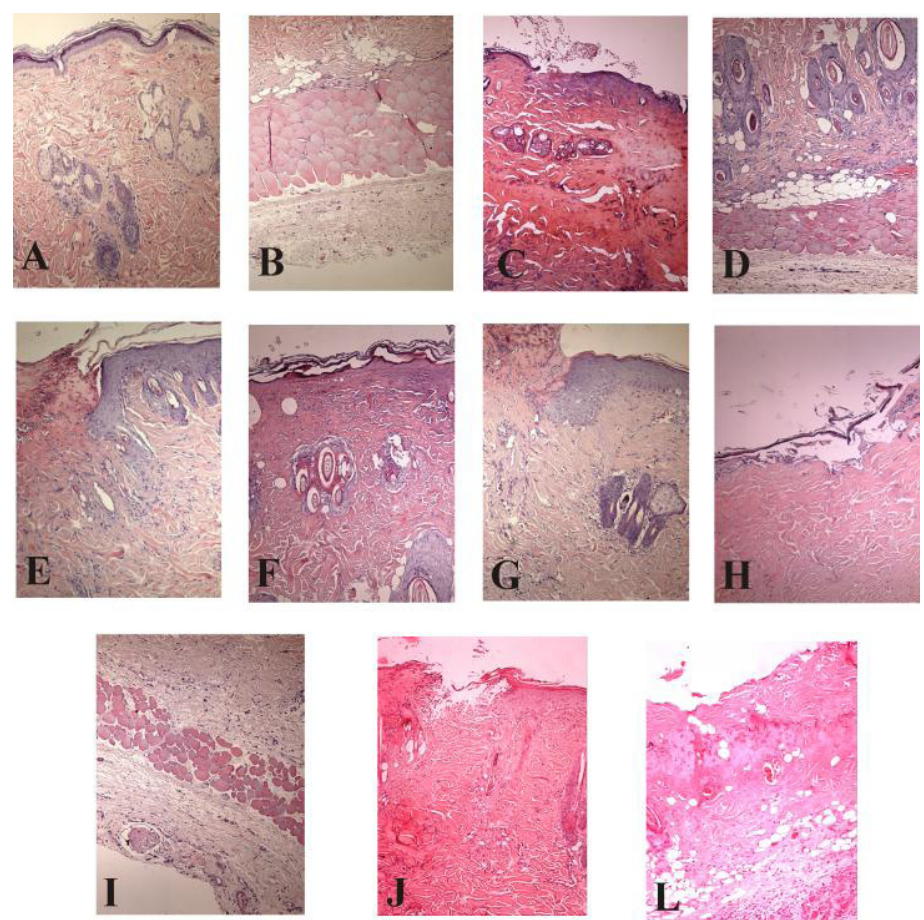

FIGURE 4 - Photomicrography of burns on post-burn day 7 (x100, magnification). A: Epidermis, dermis and pilosebaceous units from animal control (normal); B: Skeletal muscle and connective tissue from control animal; C: Partially damaged epidermis, dermis and pilosebaceous units (animal burned at $100^{\circ} \mathrm{C}$ ). D: Skeletal muscle without injury (animal burned at $100^{\circ} \mathrm{C}$ ). $\mathbf{E}$ : Incipient marginal reepithelialization (animal burned at $100^{\circ} \mathrm{C}$ ). F: Central reepithelialization (animal burned at $100^{\circ} \mathrm{C}$ ). G: Marginal reepithelialization with epidermis and dermis injury, see pilosebaceous units (burned at $150^{\circ} \mathrm{C}$ ). $\mathbf{H}$ : Central ulcer and epidermis/ dermis injury (burned at $150^{\circ} \mathrm{C}$ ). I: Skeletal muscle and hypodermis injury (burned at $150^{\circ} \mathrm{C}$ ). $\mathbf{J}$ : Marginal reepithelialization (burned at $200^{\circ} \mathrm{C}$ ). L: Injury in all layers with central ulcer and damaged muscle layer (burned at $200^{\circ} \mathrm{C}$ ). 
TABLE 1 - Presence/absence of skin structures and recovery (reepithelialization) in burned rats

\begin{tabular}{lccc}
\hline & $\begin{array}{c}\mathrm{G} 2 \\
\left(100{ }^{\circ} \mathrm{C}\right)\end{array}$ & $\begin{array}{c}\mathrm{G} 3 \\
\left(150^{\circ} \mathrm{C}\right)\end{array}$ & $\begin{array}{c}\mathrm{G} 4 \\
\left(200{ }^{\circ} \mathrm{C}\right)\end{array}$ \\
\hline Epidermis & yes & yes & yes \\
Dermis & yes & yes & yes \\
Hypodermis & no & yes & yes \\
Musculature & no & no & yes \\
Marginal reepithelialization & yes & yes & yes \\
Central reepithelialization & yes & no & no \\
\hline
\end{tabular}

Groups: $n=6$

\section{Discussion}

Over the past decade much has been discovered concerning the pathophysiology and forms of treatment of burn lesions. Different burn models have been presented. Methods for producing experimental burns included boiling water ${ }^{6}$, heated brass bar $^{7}$, heated $\left(130^{\circ} \mathrm{C}\right)$ aluminum plate ${ }^{8}$, a constant-temperature hot plate $\left(170^{\mathrm{a}} \mathrm{C}\right)$ placed over stainless steel rods ${ }^{9}$ and scalding over $45 \%$ of the body surface ${ }^{10}$.

In the present study, skin burns were inflicted by transference of energy (heat) using direct conduction (Copper/skin) utilizing different increasing temperatures $\left(100^{\circ} \mathrm{C}, 150^{\circ} \mathrm{C}\right.$ and $200^{\circ} \mathrm{C}$ ). Thermal energy transfer by conduction from a solid structure to the skin surface does not depend on the pressure employed, but mainly on the temperature gradient between the skin, the solid structure and the distance between those elements ${ }^{11}$. To the best of our knowledge, this is it the fist work where a copper template is used to induce thermal burns. Copper thermal conductivity is more efficient than other metals used by researchers ${ }^{1,7,12}$.

The results clearly demonstrated that this experimental model provided excellent contrast between normal and burned tissue at different temperatures. Thus, the highest temperature used $\left(200^{\circ} \mathrm{C}\right)$ producing lesions in all skin layers with damaged pilosebaceous units resulting in poor central reepithelialization, making being this method a good choice to evaluate drug effects in severe burnings.

Moreover, it was possible to obtain partial skin thickness burn with lesser temperatures $\left(100^{\circ} \mathrm{C}\right.$ and $\left.150^{\circ} \mathrm{C}\right)$. However, burning at $150^{\circ} \mathrm{C}$ was more deeper than $100^{\circ} \mathrm{C}$ and the central reepithelialization occurred only when the plate was heated to $100^{\circ} \mathrm{C}$. The partial-thickness burn model (using $100^{\circ} \mathrm{C}$ and $150^{\circ} \mathrm{C}$ ) in this study spares some epithelial elements within the dermis, allowing for spontaneous regeneration (reepithelialization) via proliferation and migration of epithelial cells from dermal appendages remaining at the wound site and from the wound margins ${ }^{13-14}$. Practically, it implies that a deep partial skin thickness burn should not be converted into a full skin thickness injury.
In order to achieve consistent reproducibility, the stamp pressure should be identical in all lesions and positions to ensure maximal skin contact. A major advantage of the hand-held stamp using the device weight to induce the burn lesion is that it remains constant throughout the procedure and is not related to the pressure exerted by the researcher that can present some changes due to the difficulty of figuring out the intensity of pressure that should be applied to the skin of the animal.

\section{Conclusion}

The model studied is inexpensive and easily reproducible, enabling the achievement of controlled burns with partial or total impairment of the skin in experimental animals.

\section{References}

1. Kaufman T, Lusthaus SN, Sagher U, Wexler MR. Deep partial skin thickness burns: a reproducible animal model to study burn wound healing. Burns. 1990;16(1):13-6.

2. Aulick LH, Baze WB, Johnson AA, Wilmore DW, Mason AD Jr. A large animal model of burn hypermetabolism. J Surg Res. 1981;31(4):281-7. 3. Kistler D, Hafemann B, Schmidt K. A model to reproduce predictable full-thickness burns in an experimental animal. Burns Incl Therm Inj. 1988;14(4):297-302.

4. de Mesquita CJ, Leite JA, Fechine FV, de C Rocha JL, Leite JG, Leite Filho JA, Barbosa Filho RA. Effect of imiquimod on partial-thickness burns. Burns. 2010;36(1):97-108.

5. Jandera V, Hudson DA, de Wet PM, Innes PM, Rode H. Cooling the burn wound: evaluation of different modalites. Burns. 2000; 26 (3):265-70.

6. Barbosa RCC, Guimarães SB, Vasconcelos PRC de, Chaves CR, Vasconcelos PRL de. Efeitos metabólicos da glutamina em ratos submetidos à queimadura por água fervente (escaldadura). Acta Cir Bras. 2003;18(6):537-41.

7. Meyer TN, Silva AL da. A standard burn model using rats. Acta Cir Bras. 1999;14(4): Available from URL: http://www.scielo.br/acb.

8. Medeiros AC, Ramos AMO, Dantas Filho AM, Azevedo RCF, Araújo FLFB. Tratamento tópico de queimaduras do dorso de ratos com ácido hialurônico. Acta Cir Bras. 1999;14(4). Available from: URL: http:// www.scielo.br/acb.

9. Sobral CS, Gragnani A, Morgan J, Ferreira LM. Inhibition of proliferation of Pseudomonas aeruginosa by KGF in an experimental burn model using human cultured keratinocytes. Burns. 2007;33(5):613-20.

10. Oliveira F de, Bevilacqua LR, Anaruma CA, Boldrini SC, Liberti EA. Morphological changes in distant muscle fibers following thermal injury in Wistar rats. Acta Cir Bras. 2010;25(6):525-8.

11. Davies JWL. Physiological response to burning injury. London: Academic Press; 1982.

12. Knabl JS, Bayer GS, Bauer WA, Schwendenwein I, Dado PF, Kucher C, Horvat R, Turkof E, Schossmann B, Meissl G. Controlled partial skin thickness burns: an animal model for studies of burn wound progression. Burns. 1999;25(3):229-35.

13. Dorsett-Martin WA, Wysocki A. Rat models of skin wound healing. In: Conn PM, editor. Sourcebook of models for biomedical research. Totowa: Humana Press; 2008. p.631-8.

14. Dorsett-Martin WA. Rat models of skin wound healing: a review. Wound Repair Regen. 2004;12(6):591-9. 


\section{Acknowledgements}

We are in debt to Mrs Beatrice Nuto Nobrega (medical student, UFC, Ceara, Brazil), Maria do Socorro F. Monte and Conceição da Silva Martins (technicians, Laboratory of Morphology/UFC) for their helpful technical assistance.

\section{Correspondence:}

Paulo Roberto Leitão de Vasconcelos

Federal University of Ceara

Rua Professor Costa Mendes, 1608/3 andar

60430-140 Fortaleza - CE Brasil

Tel.: (55 85)288-8063

Fax: (55 85)288-8064

paulo.vasconcelos@ufc.br

Conflict of interest: none

Financial source: $\mathrm{CNPq}$

${ }^{1}$ Research performed at Experimental Surgery Laboratory (LABCEX), Faculty of Medicine, Federal University of Ceara (UFC), Fortaleza-CE, Brazil. 